\title{
The Role of Habits of Mind (HOM) on Student's Mathematical Problem Solving Skills of Primary School
}

\author{
Indhira Asih Vivi Yandari', Supartini ${ }^{2}$, Aan Subhan Pamungkas ${ }^{3}$, Etika Khaerunnisa ${ }^{4}$ \\ 1,2,3,4 Universitas Sultan Ageng Tirtayasa; asubhanp@untirta.ac.id
}

\begin{abstract}
The research aims to describe the role of habits of minds on the student's mathematical problem solving skills. Habits of mind studied are persisting, metacognition, thinking flexibly, and applying past knowledge to a new situation. The method used in this research is quantitative correlational. Samples were taken as much as 49 fifth grade students at SDN Walantaka 1. Data collection techniques using HOM scale and essay tests. Based on data analysis results obtained average habits of mind score of 68.26 including into medium category and problem solving skills of 53.68 in low category. The results of the regression test on a significant level of $\alpha=0.05$ obtained a conclusion that there is a significant influence between habits of mind on the mathematical problem solving, with a contribution of $67.40 \%$. Based on the findings, the habits of mind plays an important role in problem solving and teachers should be able to develop that aspect.
\end{abstract}

Keywords: habits of mind, mathematical problem solving, primary school

\section{INTRODUCTION}

Student's learning process should be directed through an effective thought process so that students can put themselves in various situations by relying on their skills. Students can form good habits in their daily learning process. This habituation of learning is known as habits of mind. Habits of mind is a strong disposition and intelligent behavior. If the habit of mind takes place well then it will grow the desire and the longing of the students to think and do the positive (L \& Kallick, 2008). Habits of mind students in learning become fundamental when it gets the problem to be found solution completion. As with any mathematical problem solving skill, habits of mind also strongly supports the appearance of students in daily life. Problem solving as a first step students in developing ideas in building new knowledge and developing math skills. Problem solving skills are one aspect that needs to be a focus of attention.

The results of a preliminary study at SDN Walantaka 1 on the mathematics score of the fifth grade showed that from 53 students, who were able to reach the minimum standar of 27 student, this was one of the indicators of low student's mathematical skill. Another factor of the low mathematical skill (problem solving) is in the learning activities of students who are less accustomed to finding information but are accustomed to being the recipient of information, so that the learning process in teacher class is more dominates than students. The exercise that requires students to use less skills, the consequence that must be taken from this learning is when students are given questions that differ from their training problems or make mistakes in completing his duties because learning oriented to record and memorize is not understanding the material, such conditions affect the easy attitude of surrender or despair to complete the task.

Development of problem solving skills in mathematics learning must be continuously trained and improved, here the teacher role is very important, it must be able to generate interest 
in students to actively engage in solving the proposed problems, guiding students gradually so that students can find solutions to the problems they are facing. When the implementation of student learning is expected to understand the process and procedures, so that the students are skilled in determining and identifying the relevant conditions and data, generalizing, formulating, and organizing the skills that already owned. Eventually students will be able to learn independently about problem solving. Based on the above problems, it is necessary for students to have a habit of mind to facilitate the reason and look for solutions to problem solving both mathematics and daily life.

Based on previous research, many studies have been conducted on the enhancement of student's mathematical problem solving skills (Alba, Khotim, \& Junaedi, 2013; Ariani, 2017; Goddess, Ardana, \& Sariyasa, 2019; Komala, 2012; Minarni, 2012; Muslim, 2017; Son, 2017; Rahmatin, 2013; Ramadhani, 2017; Ristiani, Ratu, \& Yunianta, 2015; Susanti, Musd, \& Syarifuddin, 2017; Syazali, 2015; Yurniati \& Wahyuningrum, 2015) also the study about hte role of habits of mind in learning process (Bidari, 2016; Miliyawati, 2017; Nahadi, H, \& Farina, 2015; Nurmaulita, 2014; Zhok, 2016). However, there has been no research to describe the role of habits of minds on the mathematical problem solving skills of primary students.

Based on previous research, the novelty of this research is in the role description of habits of minds on the mathematical problem solving skills of primary students. Thus, the study aims to describe the role of habits of minds towards mathematical problem solving skills of primary students.

\section{THE RESEARCH METHODS}

The research method used is a correlational quantitative research method. The influence between habits of mind variables against the mathematical problem solving skill of students is demonstrated by the design of the 2 (two) variable correlational research (Riduwan, 2015).

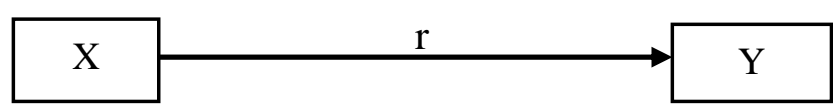

Figure 1. Correlation of Habits of Mind (X) and Mathematical Problem Solving (Y)

The sample in this study is all students fifth grade of SDN Walantaka 1 which amounted to 49 students consisting of 19 males and 30 females. The data collection techniques used in this study consist of habits of mind scale and problem solving skill tests. The test is a essay about mathematical problem solving.

Data analysis in this study includes descriptive statistics, and inferential statistics. Description of habits of mind results and tests of mathematical problem solving skills are presented in a quantitative measure, so it can be said that the data of learning outcomes is quantitative data explaining about behavioral changes after learning. Stage data processing of scale is done through analysis of the appearance of each category habits of mind students. The analysis uses percentages and is categorized according to table 1 follows: 
Table 1. Criteria of Habits of Mind

\begin{tabular}{ccc}
\hline No & Persentation $(\%)$ & Category \\
\hline 1 & $86<$ Score $\leq 100$ & Very High \\
2 & $76<$ Score $\leq 85$ & High \\
3 & $60<$ Score $\leq 75$ & Moderate \\
4 & $55<$ Score $\leq 59$ & Low \\
5 & Score $\leq 54$ & Very Low \\
\hline
\end{tabular}

Quantitative data on test results of the mathematical problem solving skill was obtained from the scoring of objective tests of the mathematical problem solving skills of each student, as follows:

Table 2. Criteria of Mathematical Problem Solving

\begin{tabular}{cc} 
Score & Category \\
\hline $80<$ Score $\leq 100$ & Very High \\
$66<$ Score $\leq 79$ & High \\
$56<$ Score $\leq 65$ & Medium \\
$40<$ Score $\leq 55$ & Low \\
Score $\leq 39$ & Very Low \\
\hline & (Ariani, 2017)
\end{tabular}

Inferential statistics are statistics that are used to analyze sample data, and the results are enforced for populations where samples are taken. (Sugiyono, 2015) The inferential statistics used are parametric because the data must be normality and linearity tes requirement. Further data is processed using correlation tests and simple regression with the help of data processing programs.

\section{THE RESULTS OF THE RESEARCH AND THE DISCUSSION}

The following data is presented in the form of score calculation of habits of mind and mathematical problem solving skills of fifth grade SDN Walantaka 1.

\section{Analyze of Student's Habits of mind}

Scale is used to collect data on habits of mind students of the fifth grade of SDN Walantaka 1. Data collection through this scale, alternative answer refers to the modified Likert scale which is: often, sometimes, never. Scoring Habits of mind students using the scoring format as in table 3 follows:

Table 3. Scale Habits of Mind scoring Format

\begin{tabular}{ccc}
\hline Alternative & Positive & Negative \\
\hline Often & 3 & 1 \\
Sometimes & 2 & 2 \\
Never & 1 & 3 \\
\hline
\end{tabular}


The grid scales the habits of mind students used in this study as follows:

Table 4. Scales of Habits of Mind Indicators

No Habits of Mind Aspects Indicators

\begin{tabular}{|c|c|c|}
\hline 1 & Persisting & $\begin{array}{l}\text { a. Students are diligent in learning } \\
\text { b. Students are accustomed to } \\
\text { demonstrating systematic methods to } \\
\text { analyse problems }\end{array}$ \\
\hline & & $\begin{array}{l}\text { c. Students are accustomed to } \\
\text { distinguishing ideas that are successful } \\
\text { and not }\end{array}$ \\
\hline 2 & Thinking about Thinking & $\begin{array}{l}\text { a. Students are accustomed to working or } \\
\text { acting as planned } \\
\text { b. Students are aware of their thoughts and } \\
\text { actions } \\
\text { c. Students are accustomed to describing } \\
\text { measures used to solve problems }\end{array}$ \\
\hline 3 & Thinking Flexibel & $\begin{array}{l}\text { a. The students are accustomed to open- } \\
\text { minded } \\
\text { b. Students have many ideas and ideas } \\
\text { about things }\end{array}$ \\
\hline & & $\begin{array}{l}\text { c. Students are able to use various } \\
\text { troubleshooting ways to solve the same } \\
\text { problem }\end{array}$ \\
\hline 4 & $\begin{array}{l}\text { Applying Past } \\
\text { Knowledge to New } \\
\text { Situation }\end{array}$ & $\begin{array}{l}\text { a. Students are able to use their own } \\
\text { knowledge to understand new issues or } \\
\text { situations. }\end{array}$ \\
\hline & & $\begin{array}{l}\text { b. Students are able to connect the } \\
\text { knowledge he has with new knowledge }\end{array}$ \\
\hline
\end{tabular}

(Bidari, 2016)

Habits of mind examined in the study was based on four categories: persisting, thinking of thinking, thinking flexible, and applying past knowledge to new situation. The calculation result of the habits of mind scale of 49 students obtained an average score of 68.26 belongs to the medium category. Classifications of habits of mind students based on the scale result are divided into five categories namely: very high, high, medium, low and very low presented in the form of the following diagram:

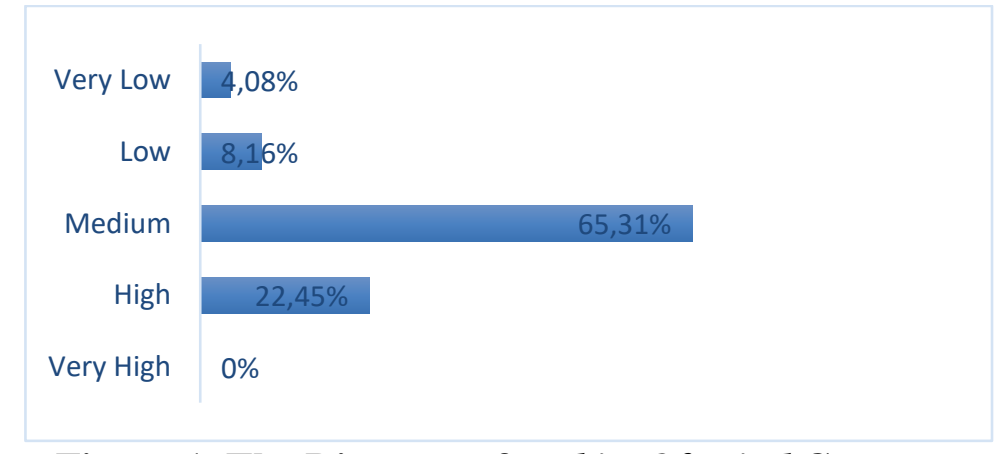

Figure 1. The Diagram of Habits Of Mind Category 
Based on the diagram in Figure 2, it can be known that the level of habits of mind that is owned by the highest student is in the medium category as many as 32 students, high category as many as 11 students, the low category as many as 4 students and the very low category as many as 2 students. The Data shows that most students have sufficient habits of mind levels. The acquisition of the average score that represents the need for innovation in learning one of them is the development of learning strategy by considering the habits of mind indicators, so that the impact on Increased habits of mind and mathematical skills of students.

The tendency habits of mind is based on counting results showing different results per category. It is shown in table 5 below:

Table 5. The Persentation of Student's Habits of Mind

\begin{tabular}{|c|c|c|}
\hline No & Category Habits of Mind & Persentation \\
\hline 1 & Persisting & $66 \%$ \\
\hline 2 & Thinking of thinking & $71 \%$ \\
\hline 3 & Thinking flexible & $68 \%$ \\
\hline 4 & $\begin{array}{l}\text { Applying past knowledge to } \\
\text { new situation }\end{array}$ & $69 \%$ \\
\hline
\end{tabular}

Average

$68,5 \%$

Based on the results of table 5 above it is shown that the tendency habits of mind the highest students in the thinking of thinking category with a percentage of as much as $71 \%$, while the fourth average category habits of mind students is classified as medium. The emergence of habits of mind students based on this scale results shows the habit to remain persistent solving the mathematical problems until completed even though it is not sure the completion is correct or incorrect. When faced with difficult mathematical problems, students try to read them many times, so that students can understand what is known, asked and the formula used. Students discuss with friends and ask the teacher when unable to resolve themselves. Students try to recall the past knowledge and experience that is then attributed to solving mathematical problems.

\section{Student's Mathematical Problem Solving}

The tests used are essay tests. Scoring guidelines on the mathematical problem solving skills used in the study are understanding problem, make a plan to solve the problem and implementing a problem solving plan. The scoring guidelines for test results are as follows

Table 6. Indicators of Mathematical Problem Solving

\begin{tabular}{cc}
\hline No & Indicators \\
\hline 1 & Understanding problems \\
2 & Make a plan for solve the problem \\
3 & Implementing a Problem solving plan \\
\hline
\end{tabular}


The test-scoring guidelines are as follows:

\section{Table 7. Scoring Guideline for Problem Solving Respons}

\section{Indicators \\ Understanding problems}

Make a plan for solve the problem

menting a

Problem solving plan

\section{Student's Respons}

No answer

Writing known/asked/sketching/model but wrong or not understanding at all Understanding information or problems with less precise

Successfully understand the problem thoroughly

No settlement step sequence at all

Strategies/settlement steps exist but are irrelevant or not/unclear

Strategy/completion steps lead to correct answers, but incomplete or incorrect answers

Presenting the correct finishing steps

No workaround at allThere is a settlement, but the procedure is unclear/wrongUsing certain correct procedures but incorrect/less complete calculationsUsing certain correct procedures

\section{Score}

0

1

2

3

0

1

2

3

0

1

2

3

(Ariani, 2017)

Based on the test results of mathematical problem solving skill was obtained an average score of 53.68 with a deviation of 28.11. The average score indicates that the skill to solve students' mathematical problems is medium, so there is a need for innovations in learning to improve mathematical problem solving skills, such as the application of methods assessment that can improve student problem solving.

Classifications of student's mathematical problem solving skills are divided into five categories namely: very high, high, medium, low and very low presented in the form of the following diagram:

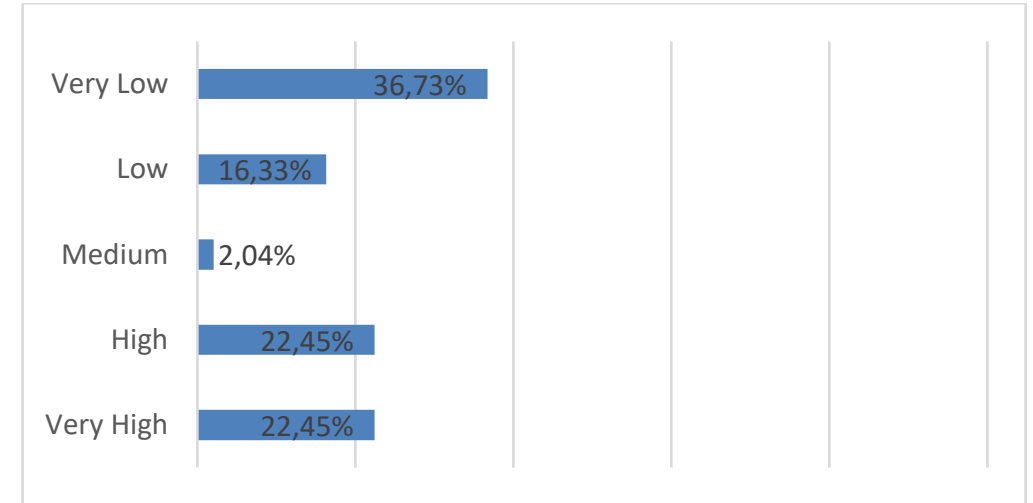

Figure 2. The Diagram of Student's Mathematical Problem Solving Catgeory 
Based on the diagram of the mathematical problem solving skill above shows that student's mathematical problem solving skills are diverse. The skill to solve mathematical problem solving in the very good category and both achieve the same result of $22.45 \%$ as many as 11 students, students who are in the medium category as many as 1 student, students who are in the low category as 8 students, while for the very high category as many as 18 students.

To know the influence and magnitude of the influence of habits of mind towards student's mathematical problem solving, it is necessary to do simple correlation test. The significance of the correlation between habits of mind to the mathematical problem solving skill of $\mathrm{t}_{\text {count }}=$ 9.858 is greater than the $t_{\text {crit }}=1.677$, it can be interpreted that there is a significant influence between the habits of mind to student's mathematical problem solving skills. The magnitude of direct influence of habits of mind over the student problem solving skill is $67.40 \%$, the remaining $32.60 \%$ is influenced by other factors beyond the habits of mind.

Based on the test results of the above correlation, in accordance with the research conducted previously by Masni stating that there is a correlation between mathematical problem solving skills and the practice of student mathematical thinking, with great influence $24.80 \%$ (Masni, 2017). According to Bifrom that there is a significant influence between the habits of mind on the student's mathematical generalization skill, with a magnitude of effect of $42.5 \%$ (Bifrom, 2016). Research findings by Qadarsih show that there is a significant influence on the habit of mind on mastering mathematical concepts, with a magnitude of $26.67 \%$.

Data on the results of the analysis shows that there is a correlate between habits of mind to the student's mathematical problem solving, which means that the good habits of mind is that it directly affects the level of student's mathematical problem solving. The correlation demonstrates the need to develop a learning strategy using habits of mind indicators. One type of habit that is seen to greatly influence the success of the individual is the habits of mind. As Miliyawati stated that habits of mind as behavior requires a discipline that is trained in such a way that it becomes a habit to strive to continue to do more wise and intelligent actions, It can be understood that any form of action performed by an individual is a consequence of his habitual habit (Miliyawati, 2017). When faced with problems, students tend to form certain intellectual patterns that can encourage individual success in resolving the problem.

The habit of continuously being performed is increasingly stronger and settled on the individual so that it is difficult to change. The habit has been cultured in individuals as a result in the world of education. Students who have experienced the learning process, their habits will appear to change. Learning habits arise due to the shrinkage of response tendencies using repeated stimulation. The habit of mind which is a framework or cognitive pattern is useful as a guideline for someone to think, act, and behave when responding to a situation both in the context of learning and in its daily environment.

When we look at the indicators of the habits of mind expressed by Costa and Kallick it is apparent that these indicators provide individuals in developing mental habits that are essential educational objectives so that students can learn about whatever they want and they need to know everything to do in his or her life. Even Costa and Kallick claim habits of mind as the most high characteristic in solving problems and is an indicator of success in academics, 
employment and social relations (L \& Kallick, 2008). A number of research from Sriyati claimed that habits of mind was self-regulation in learning and found a solution in social relations in the workplace. (Sriyati, Rustaman, \& Zainul, 2010).

Habits of Mind is the culmination of individual intelligence and by having a good habit of thinking it will be an indicator of success in academic skill one of them is problem solving skill. Habits of mind strongly supports the appearance of students in daily life. The habit of mind is the strength to practice the skill of students to determine solutions to a solution, so that it can be interpreted that habits of mind has an influence on problem solving skills.

The emergence of habits of mind in the mathematical problem solving based on the analysis performed shows that on habits of persisting or persistence when resolving the problem seen from the attitude of students who remain persistent try to resolve The problems that are given until the time expires. Although students are not sure whether the solution is obtained correct or incorrect. The statement is in accordance with the results of an analysis of student's problem solving tests. Based on student's responses, students are seen trying to find a given problem solving, but have not received the right answer.

The habits of metacognition relates to the individual's habit to understand what is known and which he does not know, predicts comparatively, assessing the readiness of diverse activities, and monitoring his mind, decision and behavior. Based on students' responses, the student's visible writing what is known, asked and wrote the formula used, it shows students act according to the plan.

Habits of thinking flexible when solving problems seen from the attitude of students who are able to receive disagreements, but students are struggling in developing ideas to solve problems. Student's ideas are fixed in what teachers have taught, so when students find mathematical questions different from examples they have difficulty developing their completion. The habit of using the knowledge and experience in the new situation is important to have when facing mathematical problems, because the mathematical problems are not available algorithms that fully determine the solution. So previous knowledge and experience in dealing with the same problem has an impact on success or absence when solving problems.

Habits of applying past knowledge to new situation. Based on the scale and students ' answers stated that in solving the mathematical problems students try to remember, open their notes and associate the knowledge they have. However, due to problems/issues given differently or new students are incorrect in determining the correct solution solutions. In general, the majority of habits of mind students in mathematical problem solving diverse than those that belong very low to very high.

Looking at the findings above, it should be necessary to make improvements and optimization of student mathematical problem solving skills, one of the efforts done is to increase the habits of mind. Doing an increase in habits of mind needs to be prepared in advance of design learning by the teacher in question. This relates to the learning strategy that needs to be developed by considering the indicators of the habits of mind, so that students have a good habit of thinking. While the score of the habit of thinking is high then expected the score of problem solving skills increased. 
Some researchers are relevant about the habits of mind and the mathematical problem solving skills of students. Sriyati stated that the application of formative assessment (feedback, self assessment and peer assessment) in various qualities of tasks, learning outcomes and shaping and improving habits of mind (Sriyati et al., 2010). Masni's research stated that there were correlations between student mathematical problem solving skills and mathematical habits of mind (Masni, 2017). Students who have the high skill of mathematical problem solving, the habit is also high, the students who have the medium skill of mathematical problem solving then his habit is also being, students who have the low skill of mathematical problem solving are low then the habit is also low. The results showed that while the habits of mind continues to be excavated, developed and trained will affect the mathematical skills of the students who are one of the problem solving skill. Habits of mind and problem solving itself is not a result of short learning, but must go through the process and habituation with the provision of formative assessment and problems that can trigger the student's thinking skills.

\section{CONCLUSION AND SUGGESTION}

Based on data analysis results acquired average habits of mind score of 68.26 and problem solving skills of 53.68. The average score of both variables belongs to a medium category. The result of influence test effect on the significant level $\alpha=0.05$ obtained $t_{\text {count }}=9.8581>t_{\text {crit }}=$ 1.677. It can be concluded that there is a significant positive influence between the habits of mind to the mathematical problem solving skills, with a magnitude of influence or contribution of $67.40 \%$.

The advice that can be given to further researchers is expected to examine problems with broader reach and need to do measurement of habits of mind in other categories, because in this research limited to only four. So the categories cannot explain the overall habits of mind that students may have.

\section{REFERENCES}

Alba, F. M., Khotim, M., \& Junaedi, I. (2013). Keefektifan Model Pembelajaran Generatif dan MMP Terhadap Kemmpuan Pemecahan Masalah. Kreano: Jurnal Matematika KreatifInovatif, 4(2), 131-137.

Ariani, S. (2017). Kemampuan Pemecahan Masalah Matematis Siswa Pada Pembelajaran Matematika Menggunakan Strategi Abduktif-Deduktif di SMA Negeri 1 Indralaya Utara. Jurnal Elemen, 3(1), 1-10.

Bidari, I. (2016). Pengaruh Habits Of Mind Terhadap Kemampuan Generalisasi Matematika Siswa. Jakarta: UIN Syarif Hidayatullah Jakarta.

Dewi, N. P. R., Ardana, I. M., \& Sariyasa. (2019). Efektivitas Model ICARE Berbantuan Geogebra Untuk Meningkatkan Kemampuan Pemecahan Masalah Matematis Siswa. JNPM ( Jurnal Nasional Pendidikan Matematika ), 3(1), 109-122.

Komala, E. (2012). Pembelajaran dengan Pendekatan Diskursif untuk Meningkatkan Kemampuan Pemecahan Masalah Matematis dan Self-Concept Siswa Sekolah Menengah 
Pertama. Tesis Pada SPS UPI. Tidak Dipublikasikan.

L, C. A., \& Kallick, B. (2008). Leading and Learning with Habits of Mind 16 Essential Characteristic for Success. USA: Association for Supervision and Curriculum Development (ASCD).

Masni, E. D. (2017). Asosiasi Kemampuan Pemecahan Masalah dan Mathematical Habits of Mind Siswa SMP. Jurnal Penelitian Pendidikan INSANI, 20(1).

Miliyawati, B. (2017). Reformulasi Strategi Habits Of Mind Matematis Terhadap Kemampuan Mathematical Critical Thingking Dalam Mewujudkan Generasi Emas Berkarakter. JNPM ( Jurnal Nasional Pendidikan Matematika ), 1(1), 24-42.

Minarni, A. (2012). Pengaruh Pembelajaran Berbasis Masalah Terhadap Kemampuan Pemecahan Masalah Matematis. In Prosiding.

Muslim, S. R. (2017). Pengaruh Penggunaan Model Project Based Learning Terhadap Kemampuan Pemecahan Masalah Matematis Peserta Didik SMA. Supremum Journal of Mathematics Education (SJME), 1(2), 88-95.

Nahadi, H, F., \& Farina, J. (2015). Effect Of Feedback In Formative Assessment In The Student Learning Activities On Chemical Course To The Formation Of Habits Of Mind. Jurnal Pendidikan IPA Indonesia, 4(1), 36-42.

Nurmaulita. (2014). Pembentukan Habits Of Mind Siswa Melalui Pembelajaran Saling Temas Pada Mata Pelajaran Fisika. Jurnal Pendidikan Fisika, 3(1), 53-58.

Putra, F. G. (2017). Eksperimentasi Pendekatan Kontekstual Berbantuan Hands On Activity (HoA) Terhadap Kemampuan Pemecahan Masalah Matematik. Al-Jabar: Jurnal Pendidikan Matematika, 8(1), 73-80.

Rahmatin, D. N. (2013). Profil berpikir kritis mahasiswa pendidikan matematika dalam memecahkan masalah nilai dan vektor eigen ditinjau dari pemetaan kemampuan aljabar. Gamatika, 3(2), 101-109.

Ramadhani, R. (2017). Kemampuan Pemecahan Masalah Matematika Siswa SMA Melalui Guided Discovery Learning Berbantuan Autograph. JPPM, 10(2), 72-81.

Riduwan. (2015). Belajar Mudah Penelitian Untuk Guru-Karyawan dan Peneliti Pemula. Bandung: Alfabeta.

Ristiani, M., Ratu, N., \& Yunianta, T. N. H. (2015). Strategi Pemecahan Masalah Dalam Menyelesaikan Soal Cerita Pada Materi Persamaan Dan Pertidaksamaan Linier Satu Variabel. Satya Widya, 31(1), 8-16.

Sriyati, S., Rustaman, \& Zainul, A. (2010). Kontribusi Asesmen Formatif Terhadap Habits of Mind Mahasiswa Biologi. Jurnal Pengaajaran MIPA, 15(2), 77-86.

Sugiyono. (2015). Metode Penelitian Kombinasi (Mixed Methods). Bandung: Alfabeta.

Susanti, Musdi, E., \& Syarifuddin, H. (2017). Pengembangan Perangkat Pembelajaran Matematika Materi Statistik Berbasis Penemuan Terbimbing Untuk Meningkatkan 
Kemampuan Pemecahan Masalah Matematis Materi Statistika. Jurnal JNPM ( Jurnal Nasional Pendidikan Matematika ), 1(2), 305-319.

Syazali, M. (2015). Pengaruh Model Pembelajaran Creative Problem Solving Berbantuan Maple II Terhadap Kemampuan Pemecahan Masalah Matematis. Al-Jabar, 6(1), 91-98.

Yurniati, \& Wahyuningrum, E. (2015). Pembelajaran Berbasis ICARE Dalam Tutorial Online Untuk Meningkatkan Kemampuan Pemecahan Masalah Matematis Mahasiswa UT. Infinity, 4(2), 182-189.

Zhok, A. (2016). Habit and Mind. On The Teleology of Mental Habits. Phenomenology and Mind, O(6), 90-99. 